\title{
PERLINDUNGAN HUKUM TERHADAP KONSUMEN E-COMMERCE DAN PENYELESAIAN SENGKETA KONSUMEN E-COMMERCE DALAM PERDAGANGAN PRODUK WANITA DI KOTA PEKANBARU
}

\author{
Desi Sommaliagustina ${ }^{1}$, Yulia Fatma ${ }^{2}$
}

\begin{abstract}
ABSTRAK
Penelitian ini dilatarbelakangi oleh semakin banyaknya orang yang melakukan perdagangan elektronik. Salah satunya adalah perdagangan produk wanita secara elektronik di Kota Pekanbaru. Perdagangan elektronik sering menciptakan hambatan seperti prosedur pembayaran, perlindungan hukum, tanda tangan elektronik, dan mekanisme penyelesaian sengketa yang terjadi di masa depan. Perdagangan elektronik juga harus mematuhi hukum positif. Meskipun ada sejumlah hambatan dalam perdagangan secara elektronik namun jenis perdagangan ini masih memiliki peminatnya. Selain itu mengabaikan perkembangan teknologi akan memiliki dampak negatif di masa depan, sehingga keterbukaan dan sifat proaktif dan antisipatif adalah alternatif yang dapat dipilih dalam menghadapi dinamika perkembangan teknologi termasuk perkembangan perdagangan seperti perdagangan elektronik atau yang biasa disebut dengan perdagangan elektronik atau e-commerce. Hal ini karena Indonesia telah menjadi bagian dari pasar e-commerce global. Fokus penelitian ini adalah: Pertama,Untuk mengetahui perlindungan hukum terhadap konsumen dalam perdagangan produk wanita secara elektronik di Kota Pekanbaru; Kedua, Untuk mengetahui penyelesaian hukumnya jika terjadi sengketa oleh para pihak dalam perdagangan produk wanita secara elektronik di Kota Pekanbaru. Tujuan dari penelitian ini adalah untuk mengetahui bagaimana perlindungan hukum terhadap konsumen dalam perdagangan produk wanita secara elektronik di Kota Pekanbaru dan untuk mengetahui bagaimana penyelesaian hukumnya jika terjadi sengketa oleh para pihak dalam perdagangan produk wanita secara elektronik di Kota Pekanbaru. Hasil penelitian menunjukkan bahwa instrumen hukum di Indonesia telah memberikan perlindungan hukum kepada konsumen meskipun mereka belum sepenuhnya seperti UUPK dan UU ITE, tetapi masih ada konsumen yang tidak memahami UUPK dan UU ITE. Dan masih ada konsumen yang tidak memahami hak dan kewajiban mereka sebagai konsumen. Mekanisme penyelesaian sengketa yang tersedia adalah melalui pengadilan atau di luar pengadilan.
\end{abstract}

Kata kunci: Perlindungan Hukum; E-commerce; Penyelesaian Sengketa.

\section{ABSTRACT}

This research is motivated by the increasing number of people doing electronic commerce. One of them is trading women's products electronically in Pekanbaru City. Electronic trading often creates barriers such as payment procedures, legal protection, electronic signatures, and future dispute resolution mechanisms. Electronic commerce must also comply with positive law. Although there are a number of obstacles in electronic commerce, this type of trade still has an interest. In addition, ignoring technological developments will have a negative impact in the

\footnotetext{
${ }^{1}$ Dosen Program Studi Ilmu Hukum, Fakultas Hukum, Universitas Muhammadiyah Riau, Email: desisommalia@umri.ac.id

${ }^{2}$ Dosen Program Studi Teknik Informatika, Fakultas Ilmu Komputer, Universitas Muhammadiyah Riau, Email: yuliafatma@umri.ac.id
} 
future, so that openness and proactive and anticipatory nature are alternatives that can be chosen in facing the dynamics of technological developments including trade developments such as electronic commerce or commonly referred to as electronic trading or e-commerce. This is because Indonesia has become part of the global e-commerce market. The focus of this research is 1) What is the legal protection of consumers in the trade of women's products electronically in Pekanbaru City? 2) What is the legal settlement if a dispute arises by the parties in the electronic trade in women's products in Pekanbaru City? The purpose of this study is to find out how the legal protection of consumers in the trade of women's products electronically in Pekanbaru City and to find out how to resolve their laws in the event of a dispute by the parties in the trade of women's products electronically in Pekanbaru City. The results showed that legal instruments in Indonesia have provided legal protection to consumers even though they are not fully like the UUPK and the ITE Law, but there are still consumers who do not understand the UUPK and the ITE Law. And there are still consumers who do not understand their rights and obligations as consumers. Available dispute resolution mechanisms are through the court or outside the court.

Keywords: Legal Protection; E-commerce; Dispute Resolution.

\section{PENDAHULUAN}

Perkembangan teknologi informasi yang terjadi hari ini membawa akibat pada berkembangnya aktifitas perdagangan, dimana cara berdagang mengalami perubahan. Salah satu perubahan tersebut dikenal dengan perdagangan atau transaksi melalui media elektonik atau dalam bahasa Inggris disebut dengan electronic commerce (e-commerce). Perkembangan $e$ commerce tentunya tidak terlepas dari laju pertumbuhan internet karena e-commerce berjalan melalui jaringan internet, tanpa internet transaksi elektronik sulit untuk dijalankan. Pengertian transaksi elektronik menurut Sukarmi, ${ }^{3}$ adalah: perbuatan hukum yang dilakukan dengan menggunakan komputer, jaringan komputer, atau media elektronik lainnya. Menurut Wawan Muhwan Hariri, electronic commerce transaction adalah transaksi dagang antara penjual dan pembeli untuk menyediakan barang, jasa, atau mengambil alih hak. Kontrak ini dilakukan dengan media elektronik (digital medium) tanpa dihadiri para pihak yang melakukan transaksi. Medium ini terdapat di dalam jaringan umum dengan sistem terbuka, yaitu internet atau world wide web dimana transaksi ini terjadi terlepas dari batas wilayah dan syarat nasional. ${ }^{4}$

Bisnis e-commerce dari pengertian di atas dapat dikatakan memakai sistem terbuka. Sistem terbuka pada bisnis e-commerce membuat batas-batas antar wilayah menjadi kurang jelas, dimana dalam transaksi elektronik perdagangan barang dan/atau jasa dapat melintasi batas-batas

\footnotetext{
${ }^{3}$ Sukarmi, Cyber Law Kontrak Elektronik Dalam Bayang-Bayang Pelaku Usaha, Bandung: Pustaka Sutra, 2008, hlm. 66.

${ }^{4}$ Wawan Muhwan Hariri, Hukum Perikatan Dilengkapi Hukum Perikatan Dalam Islam, Bandung: CV Pustaka Setia, 2011 , hlm. 337.
} 
wilayah suatu negara dengan bebas. Kondisi ini karena pertumbuhan ekonomi dunia yang semakin meluas dan negara Indonesia merupakan bagian dari perkembangan ekonomi dunia. Ditambah lagi dengan kenyataan bahwa pertumbuhan penggunaan internet di Indonesia cukup pesat.

Pertumbuhan pengguna internet yang pesat membuat internet menjadi salah satu media yang efektif bagi perusahaan maupun perseorangan untuk memperkenalkan dan menjual barang atau jasa kepada konsumen dari seluruh dunia. E-commerce merupakan model bisnis modern yang tidak perlu menghadirkan pelaku bisnis secara langsung dan tidak menggunakan tanda tangan asli. Penggunaan tanda tangan elektronik dikarenakan dalam Pasal 11 ayat (1) UndangUndang Nomor 11 Tahun 2008 tentang Informasi dan Transaksi Elektronik (selanjutnya disingkat UU ITE) tanda tangan elektronik memiliki kekuatan hukum dan akibat hukum yang sah selama memenuhi persyaratan yang ditentukan. Adapun bunyi Pasal 11 ayat (1) UU ITE adalah sebagai berikut:

(1) Tanda Tangan Elektronik memiliki kekuatan hukum dan akibat hukum yang sah selama memenuhi persyaratan sebagai berikut:

a. Data pembuatan Tanda Tangan Elektronik terkait hanya kepada Penanda Tangan;

b. Data pembuatan Tanda Tangan Elektronik pada saat proses penandatanganan elektronik hanya berada dalam kuasa Penanda Tangan;

c. Segala perubahan terhadap Tanda Tangan Elektronik yang terjadi setelah waktu penandatanganan dapat diketahui;

d. Segala perubahan terhadap Informasi Elektronik yang terkait dengan Tanda Tangan Elektronik tersebut setelah waktu penandatanganan dapat diketahui;

e. Terdapat cara tertentu yang dipakai untuk mengidentifikasi siapa Penandatangannya; dan

f. Terdapat cara tertentu untuk menunjukkan bahwa si penanda tangan telah memberikan persetujuan terhadap Informasi Elektronik yang terkait.

Pasal 11 ayat (1) UU ITE tersebut menegaskan bahwa tanda tangan elektronik dianggap sah apabila memenuhi syarat-syarat yang telah ditentukan, sehingga transaksi elektronik dapat dilakukan dengan menggunakan media elektonik yang terhubung dengan jaringan internet. Kota Pekanbaru dipilih sebagai lokasi penelitian, dikarenakan Kota Pekanbaru merupakan salah satu kota dengan pertumbuhan perekonomian yang pesat. Wilayah Kota Pekanbaru yang strategis 
menjadikan Kota Pekanbaru sebagai pusat perdagangan. Perdagangan dilakukan tidak saja secara langsung yakni bertemunya antara penjual dan pembeli, namun juga dilakukan secara elektronik.

Salah satu contoh produk yang diperdagangkan di Kota Pekanbaru adalah produk-produk wanita seperti jilbab, pakaian, tas, sepatu, serta aneka kosmetik. Penawan yang banyak dilakukan secara online melalui website oleh penjual kepada pembeli membuat perdagangan secara elektronik berkembang cukup pesat di Kota Pekanbaru, salah satunya adalah perdangan yang berkaitan dengan produk wanita. Beberapa penyebab berkembangnya perdagangan produk wanita secara elektronik di Kota Pekanbaru dikarenakan mudahnya para konsumen mengunduh aplikasi belanja online pada telepon genggam yang salah satu penggunanya adalah wanita. Serta karena wanita lebih cenderung tergiur untuk berbelanja dengan penawaran-penawaran yang diberikan oleh pemilik toko online. Namun, diantara beberapa kemudahan berbelanja online terdapat pula hal negatif lainnya pada saat konsumen berbelanja secara elektronik. Misalnya terdapat ketidak cocokan antara barang yang dipesan dengan yang diterima oleh konsumen. Hal ini dikarenakan konsumen sebagai pembeli tidak bisa melihat langsung barang yang dipesan menggunakan media elektronik. Berdasarkan uraian di atas, perlindungan hukum terhadap konsumen dalam e-commerce adalah hal yang sangat diperlukan terutama di era perdagangan bebas seperti hari ini. Dari hal tersebut maka penulis memilih judul penelitian "Perlindungan Hukum Terhadap Konsumen Dalam Perdagangan Produk Wanita Secara Elektronik Di Kota Pekanbaru".

Bertitik tolak dari pengantar masalah sebagaimana diuraikan dalam latar belakang masalah tersebut, maka permasalahan penelitian ini dapat dirumuskan sebagai berikut: 1) Bagaimana perlindungan hukum terhadap konsumen dalam perdagangan produk wanita secara elektronik di Kota Pekanbaru? 2) Bagaimana penyelesaian hukumnya jika terjadi sengketa oleh para pihak dalam perdagangan produk wanita secara elektronik di Kota Pekanbaru?

\section{METODE PENELITIAN}

Penelitian ini adalah penelitian hukum sosiologis dengan analisis data yang digunakan adalah menggunakan deskriptif kualitatif, yaitu pengolahan data yang didasarkan pada hasil studi lapangan yang kemudian dipadukan dengan data yang diperoleh dari studi kepustakaan. Selain itu, pendekatan yuridis sosiologis juga dilakukan dalam penelitian ini. Pendekatan yuridis sosiologis, yaitu di dalam menghadapi permasalahan yang dibahas berdasarkan peraturan- 
peraturan yang berlaku kemudian dihubungkan dengan kenyataan-kenyataan yang terjadi dalam masyarakat. Dalam menunjang dan melengkapi data sekunder, maka dilakukan penelitian lapangan guna memperoleh data primer. Penelitian ini dibatasi pada objek konsumen produk wanita dalam perdagangan secara elektronik di Kota Pekanbaru.

\section{HASIL PENELITIAN DAN PEMBAHASAN}

\subsection{Perlindungan Hukum Terhadap Konsumen E-Commerce}

Pembangunan dan perkembangan perekonomian dibidang perindustrian dan perdagangan nasional telah menghasilkan berbagai variasi barang dan/ atau jasa yang dapat dikonsumsi. Ditambah dengan globalisasi dan perdagangan bebas yang didukung oleh kemajuan teknologi telekomunikasi kiranya memperluas ruang gerak arus transaksi barang dan jasa. Akibatnya barang dan/ atau jasa yang ditawarkan bervariasi baik produksi luar negeri maupun produksi dalam negeri. ${ }^{5}$ Aktivitas perdagangan yang terjadi lintas negara tersebut bisa dilakukan melalui media elektronik dan memberi keuntungan bagi konsumen karena konsumen bisa membeli barang tanpa bertemu langsung dengan penjual dan tanpa mendatangi toko. Transaksi elektronik disamping memiliki kelebihan bagi konsumen, terdapat pula hal lain yang tidak menguntungkan. Hal ini sebagaimana yang disampaikan oleh Amhadi Miru dan Sutarman Yodo, ${ }^{6}$ bahwa kondisi seperti ini disatu pihak mempunyai manfaat bagi konsumen karena kebutuhan akan barang dan/ atau jasa yang diinginkan dapat terpenuhi serta semakin terbuka lebar, karena adanya kebebasan untuk memilih aneka jenis dan kualitas barang dan/ atau jasa sesuai dengan keinginan dan kemampuan konsumen. Dimana sisi lain, dapat mengakibatkan kedudukan pelaku usaha dan konsumen menjadi tidak seimbang dan konsumen berada pada posisi yang lemah, yang menjadi objek aktivitas bisnis untuk meraup keuntungan yang sebesar-besarnya oleh pelaku usaha melalui berbagai promosi, cara penjualan, serta penerapan perjanjian baku yang merugikan konsumen.

Aktifitas perdagangan yang berpotensi merugikan konsumen menyebabkan konsumen perlu mendapatkan perlindungan. Konsumen dalam hal ini termasuk konsumen yang membeli barang dengan cara melakukan transaksi secara elektronik. Yang dimaksud dengan perlindungan konsumen adalah segala upaya yang menjamin adanya kepastian hukum untuk memberikan

\footnotetext{
${ }_{6}^{5}$ Ahmadi Miru, dan Sutarman Yodo, Hukum Perlindungan Konsumen, Jakarta: PT RajaGrafindo Persada, 2010, hlm. 37. 
perlindungan kepada konsumen, hal ini sebagaimana yang diatur dalam Pasal 1 Ayat (1) Undang-undang Perlindungan Konsumen. Konsumen dalam penelitian ini adalah konsumen yang melakukan transaksi elektronik. Pasal 3 UU ITE menyebutkan bahwa pemanfaatan teknologi informasi, dan transaksi elektronik dilaksanakan berdasarkan asas kepastian hukum, manfaat, kehati-hatian, itikad baik, dan kebebasan memilih teknologi atau netral teknologi. ${ }^{7}$ Sementara itu, Gemala Dewi dkk, ${ }^{8}$ menyebutkan bahwa dalam e-commerce seorang penjual memberikan penawaran terhadap barang yang dimilikinya untuk dijual melalui media elektronik, yaitu internet dengan memasukkan penawaran tersebut dalam situs, baik yang ia kelola sendiri untuk melakukan perdagangan atau memasukkannya dalam situs lain. Pembeli di sini dapat leluasa memilih transaksi mana yang sesuai dengan yang ia cari. Dalam menjelajah situs dalam internet, pembeli layaknya orang yang berbelanja secara konvensional dengan melihat etalaseetalase yang dipajang oleh tiap-tiap toko dan jika ia menemukan sesuatu yang ia cari, maka ia dapat melakukan transaksi dengan penjual yang melakukan penawaran dalam situs tersebut yang diandaikan dengan toko secara konvensional.

Kegiatan e-commerce adalah kegiatan bisnis. Dalam kegiatan bisnis menurut Sukarmi, ${ }^{9}$ terdapat hubungan yang saling membutuhkan antara pelaku usaha dengan konsumen (pemakai barang dan atau jasa). Kepentingan pelaku usaha adalah memperoleh laba dari transaksi dengan konsumen, sedangkan kepentingan konsumen adalah memperoleh kepuasan melalui pemenuhan kebutuhannya terhadap produk barang dan atau jasa. Pelaku usaha dalam pengertian penelitian ini adalah setiap orang perseorangan atau badan usaha, baik yang berbentuk badan hukum maupun bukan badan hukum yang didirikan dan berkedudukan atau melakukan kegiatan dalam wilayah hukum negara Republik Indonesia, baik sendiri maupun bersama-sama melalui perjanjian menyelenggarakan kegiatan usaha dalam berbagai bidang ekonomi, sebagaimana yang terdapat pada Pasal 1 ayat (3) Undang Undang Nomor 8 Tahun 1999 tentang Perlindungan Konsumen. Jo Pasal 1 ayat (5) Undang-Undang Nomor 5 Tahun 1999 tentang Larangan Praktek Monopoli dan Persaingan Usaha Tidak Sehat.

Pengertian konsumen dalam penelitian ini adalah sebagaimana yang diatur dalam Pasal 1 Ayat (2) Undang-Undang Nomor 8 Tahun 1999 tentang Perlindungan Konsumen (selanjutnya

\footnotetext{
${ }^{7}$ Danrivanto Budhijanto, Hukum Telekomunikasi, Penyiaran dan Teknologi Informasi: Regulasi dan Konvergensi, Bandung: PT Refika Aditama, 2010, hlm. 138.

${ }^{8}$ Gemala Dewi, dkk, Hukum Perikatan Islam Di Indonesia, Depok: Prenadamedia Group, 2018, hlm. 181.

${ }^{9}$ Sukarmi, Cyber Law,Op.Cit, hlm. 63.
} 
disingkat UUPK) yaitu: "Setiap orang pemakai barang dan/atau jasa yang tersedia dalam masyarakat, baik bagi kepentingan diri sendiri, keluarga, orang lain maupun makhluk hidup lain dan tidak untuk diperdagangkan." Adapun pengertian konsumen dalam UUPK adalah konsumen akhir. Sebagaimana yang telah disebutkan, konsumen dalam penelitian ini adalah konsumen yang melakukan transaksi secara elektronik atau e-commerce. Konsumen e-commerce merupakan konsumen yang perlu mendapatkan perhatian. Karena di era modern dan digital saat ini, aktifitas perdagangan e-commerce telah menjadi pilihan banyak orang.

Hal ini seperti data Bank Indonesia (BI) menyebutkan, bahwa transaksi toko online (ecommerce) di Indonesia sepanjang 2018 lalu mencapai Rp 77,766 triliun. Angka ini meroket $151 \%$ dibandingkan tahun sebelumnya yang mencapai Rp 30,942 triliun. ${ }^{10}$ Data ini diperkuat dengan hasil penelitian yang dilakukan oleh peneliti terhadap konsumen e-commerce dalam perdagangan produk wanita di Kota Pekanbaru yang menyebutkan terdapat beberapa kelebihan berbelanja secara elektronik. Kelebihan tersebut dapat dilihat dalam tabel berikut ini:

Tabel 3.1

Kelebihan Berbelanja Secara Elekronik

\begin{tabular}{|c|c|c|c|}
\hline No & Nama Konsumen & $\begin{array}{c}\text { Produk Wanita yang } \\
\text { Dibeli }\end{array}$ & $\begin{array}{c}\text { Kelebihan Berbelanja } \\
\text { Secara Online }\end{array}$ \\
\hline 1. & Dede Mutiara Yaste & $\begin{array}{l}\text { 1. Jilbab; } \\
\text { 2. Baju; } \\
\text { 3. Kosmetik (lipstik) }\end{array}$ & $\begin{array}{l}\text { 1. Waktu lebih efisien; } \\
\text { 2. Lebih praktis karena } \\
\text { berbelanja bisa melalui } \\
\text { handpone. }\end{array}$ \\
\hline 2. & Rahmannur Ikhuanza & $\begin{array}{l}\text { 1. Baju; } \\
\text { 2. Tas; } \\
\text { 3. Boks sepatu; } \\
\text { 4. Jam tangan wanita. }\end{array}$ & $\begin{array}{l}\text { 1. Barang yang dibeli } \\
\text { langsung diantar ke } \\
\text { rumah atau ke alamat; } \\
\text { 2. Lebih praktis; } \\
\text { 3. Bisa melihat-lihat } \\
\text { barang-barang yang } \\
\text { dijual hanya melalui } \\
\text { handphone. }\end{array}$ \\
\hline
\end{tabular}

${ }^{10}$ Wahyu Daniel, Wow! Transaksi e-Commerce RI 2018 Capai Rp 77 T, Lompat 151\%,https://www.cnbcindonesia.com/tech/2019031110182337-59800/wow-transaksi-e-commerce-ri-2018-capai-rp-77-t-lompat-151 (dikutip tanggal 27 Agustus 2019) 


\begin{tabular}{|c|c|c|c|}
\hline 3. & Rini Ratna Sari & $\begin{array}{l}\text { 1. } \text { Baju; } \\
\text { 2. Tas; } \\
\text { 3. Jaket }\end{array}$ & $\begin{array}{l}\text { 1. Waktu lebih efisien; } \\
\text { 2. Lebih praktis; }\end{array}$ \\
\hline 4. & Roza Efnita & $\begin{array}{l}\text { 1. Baju gamis; } \\
\text { 2. Jilbab; } \\
\text { 3. Tas; } \\
\text { 4. Sepatu. }\end{array}$ & $\begin{array}{l}\text { 1. } \text { Berbelanja lebih } \\
\text { mudah dan praktis; } \\
\text { 2. Harga barang yang } \\
\text { dijual lebih murah }\end{array}$ \\
\hline
\end{tabular}

Sumber: Data diolah dari wawancara peneliti dengan konsumen dalam perdagangan produk wanita di Kota Pekanbaru tahun 2019.

Tabel tersebut menunjukkan konsumen dalam perdagangan produk wanita di Kota Pekanbaru memilih membeli barang secara elektronik karena terdapat beberapa kelebihan seperti waktu lebih efisien, berbelanja lebih mudah dan praktis, bisa melihat-lihat barang yang dijual hanya melalui handphone, barang yang dibeli langsung diantar ke alamat konsumen, dan harga barang yang ditawarkan lebih murah dibandingkan berbelanja secara konvensional. ${ }^{11}$ Namun, di lain pihak, kondisi globalisasi saat ini dapat mengakibatkan kedudukan pelaku usaha dan konsumen menjadi tidak seimbang. Konsumen dapat menjadi obyek aktivitas bisnis dari pelaku usaha melalui iklan, promosi, cara penjualan, serta penerapan perjanjian-perjanjian standar yang merugikan konsumen.

Berkaitan dengan keamanan dalam transaksi elektronik sebagaimana yang dikemukakan oleh Onno W. Purbo, bahwa keamanan sistem informasi berbasis internet menjadi suatu keharusan untuk diperhatikan, karena jaringan komputer internet bersifat publik dan global pada dasarnya tidak aman. Pada saat data terkirim dari suatu komputer ke komputer lain di dalam internet, data itu akan melewati sejumlah komputer lain yang berarti akan memberi kesempatan pada pengguna internet lain untuk menyadap atau mengubah data tersebut. ${ }^{12}$ Sistem keamanan yang baik pada saat konsumen melakukan transaksi elektronik merupakan hal penting. Namun, yang tak kalah pentingnya adalah pendidikan bagi konsumen dan kesadaran konsumen akan hak-hak dan kewajibannya yang harus terpenuhi sebagai warga negara.

\footnotetext{
${ }^{11}$ Diolah dari hasil wawancara dengan konsumen e-commerce dalam perdagangan produk wanita di Kota Pekanbaru, Tahun 2019.

12 Onno W Purbo dan Tony Wiharjito, Keamanan Jaringan Internet, PT. Elex Media Komputindo, Jakarta: Kelompok Gramedia, 2002 , hlm. 1.
} 
Menjamin Perlindungan Konsumen,UUPK telah mengatur beberapa hal yang dilarang bagi pelaku usaha sebagaimana yang diatur dalam Bab IV 'Perbuatan yang Dilarang' bagi pelaku usaha. Dalam hal ini UUPK dapat memaksa pelaku usaha untuk mentaati isi UUPK.Dan hal ini ditegaskan pula dalam UUPK seperti pada Bab VI 'Tanggungjawab Pelaku Usaha'. Perlindungan hukum terhadap konsumen yang diberikan dalam UUPK dikarenakan seringnya terjadi pelanggaran terhadap hak-hak konsumen. Berdasarkan hasil penelitian, terdapat beberapa permasalahan yang berkaitan dengan hak-hak konsumen $e$-commerce dalam perdagangan produk wanita di Kota Pekanbaru, yaitu: ${ }^{13}$

a. Ukuran barang yang dipesan tidak sesuai dengan yang diterima;

b. Tingkat kesesuaian barang antara yang dipesan dengan yang diterima hanya sekitar 70 persen dan 30 persennya lagi cenderung tidak sesuai antara yang dipesan dengan yang diterima;

c. Barang yang sudah dalam proses pemesanan tidak kunjung dikirim oleh penjual dengan alasan stok habis;

d. Merasa tertipu ketika barang yang sudah diiklankan di internet, lalu dipesan namun tidak dikirimkan dengan alasan tidak ada stok;

e. Kualitas barang yang diiklankan di internet tidak sesuai dengan barang yang diterima;

f. Barang yang dipesan tidak bisa dipegang langsung sehingga berbeda antara kualitas barang yang diiklankan dengan yang diterima;

g. Ukuran barang yang dipesan tidak sesuai antara yang dipesan dengan yang diiklankan;

h. Tingkat kecerahan warna tidak sesuai antara yang diiklankan di internet dengan yang diterima;

i. Tidak bisa melihat isi dalam produk (tas) sehingga tidak bisa mendapatkan informasi sebuah produk secara utuh;

j. Tidak sesuai apa yang diiklankan melalui gambar dengan diterima;

k. Barang terlambat datang.

Permasalahan yang dialami konsumen sebagaimana tersebut di atas menunjukkan bahwa konsumen masih sering berada pada kondisi yang dirugikan sehingga untuk mencegah terjadinya kerugian terhadap konsumen diperlukan perlindungan hukum. Perlindungan terhadap konsumen

\footnotetext{
${ }^{13}$ Diolah dari hasil wawancara dengan konsumen e-commerce dalam perdagangan produk wanita di Kota Pekanbaru, Tahun 2019.
} 
diberikan oleh Undang-Undang No.8 Tahun 1999 tentang Perlindungan Konsumen (UUPK) diantaranya mengatur mengenai hak dan kewajiban konsumen. Beberapa hak konsumen diatur dalam Pasal 4 UUPK. Adapun bunyi Pasal 4 UUPK sebagai berikut:

a. Hak atas kenyamanan, keamanan, dan keselamatan dalam mengkonsumsi barang dan/atau jasa;

b. Hak untuk memilih serta mendapatkan barang dan/atau jasa sesuai dengan nilai tukar dan kondisi serta jaminan yang dijanjikan;

c. Hak atas informasi yang benar, jelas, dan jujur;

d. Hak untuk didengar pendapat dan keluhannya;

e. Hak untuk mendapatkan advokasi, perlindungan, dan upaya penyelesaian sengketa perlindungan konsumen secara patut;

f. Hak untuk mendapat pembinaan dan pendidikan konsumen;

g. Hak untuk diperlakukan atau dilayani secara benar dan jujur serta tidak diskriminatif;

h. Hak untuk mendapatkan kompensasi, ganti rugi dan/atau penggantian, apabila barang dan/atau jasa yang diterima tidak sesuai dengan perjanjian atau tidak sebagaimana mestinya.

Selain memiliki hak, konsumen juga memiliki beberapa kewajiban yang diatur dalam Pasal 5 UUPK. Kewajiban tersebut adalah:

a. Membaca atau mengikuti petunjuk informasi dan prosedur pemakaian atau pemanfaatan barang dan/atau jasa, demi keamanan dan keselamatan;

b. Beritikad baik dalam melakukan transaksi pembelian barang dan/atau jasa;

c. Membayar sesuai dengan nilai tukar yang disepakati;

d. Mengikuti upaya penyelesaian hukum sengketa perlindungan konsumen secara patut.

Hak dan kewajiban konsumen sebagaimana yang telah disebutkan dalam UUPK, merupakan hal yang perlu diketahui dan dipahamai oleh konsumen agar terhindar dari hal-hal yang merugikan konsumen. Disamping itu untuk mencegah terjadinya kerugian pada konsumen maka posisi antara konsumen dan pelaku usaha harus seimbang. Hal ini seperti yang dikatakan oleh Ahmadi Miru sebagaimana yang dikutip oleh Agus Yudha Hernoko, ${ }^{14}$ yang menyebutkan bahwa keseimbangan antara konsumen produsen dapat dicapai dengan meningkatkan

\footnotetext{
${ }^{14}$ Agus Yudha Hernoko, Hukum Perjanjian Asas Proporsionalitas dalam Kontrak Komersial, Jakarta: Kencana Prenada Media Group, 2013 , hlm.
} 28 
perlindungan terhadap konsumen karena posisi produsen lebih kuat dibandingkan dengan konsumen. Sedangkan perlindungan terhadap konsumen e-commerce selain diatur dalam UUPK juga diatur dalam UU lain. UU yang dimaksud adalah UU ITE. Dalam UU ITE yang berkaitan dengan transaksi elektronik bisa dilihat pada Pasal 17, 18 dan 19. Adapun bunyi Pasal 17, 18 dan 19 UU ITE sebagai berikut:

Pasal 17

(1) Penyelenggaraan Transaksi Elektronik dapat dilakukan dalam lingkup publik ataupun privat. (2) Para pihak yang melakukan Transaksi Elektronik sebagaimana dimaksud pada ayat (1) wajib beriktikad baik dalam melakukan interaksi dan/atau pertukaran Informasi Elektronik dan/atau Dokumen Elektronik selama transaksi berlangsung. (3) Ketentuan lebih lanjut mengenai penyelenggaraan Transaksi Elektronik sebagaimana dimaksud pada ayat (1) diatur dengan Peraturan Pemerintah.

Pasal 18

(1) Transaksi Elektronik yang dituangkan ke dalam Kontrak Elektronik mengikat para pihak. (2) Para pihak memiliki kewenangan untuk memilih hukum yang berlaku bagi Transaksi Elektronik internasional yang dibuatnya. (3) Jika para pihak tidak melakukan pilihan hukum dalam Transaksi Elektronik internasional, hukum yang berlaku didasarkan pada asas Hukum Perdata Internasional. (4) Para pihak memiliki kewenangan untuk menetapkan forum pengadilan, arbitrase, atau lembaga penyelesaian sengketa alternatif lainnya yang berwenang menangani sengketa yang mungkin timbul dari Transaksi Elektronik internasional yang dibuatnya. (5) Jika para pihak tidak melakukan pilihan forum sebagaimana dimaksud pada ayat (4), penetapan kewenangan pengadilan, arbitrase, atau lembaga penyelesaian sengketa alternatif lainnya yang berwenang menangani sengketa yang mungkin timbul dari transaksi tersebut, didasarkan pada asas Hukum Perdata Internasional.

Pasal 19

Para pihak yang melakukan Transaksi Elektronik harus menggunakan Sistem Elektronik yang disepakati.

Undang-undang lainnya yang mengatur tentang perlindungan hukum terhadap konsumen e-commerce adalah Undang-undang Republik Indonesia No 7 Tahun 2014 tentang Perdagangan (selanjutnya disingkat UU Perdagangan).Undang-Undang Perdagangan mengatur perdagangan sistem elektronik dengan ketentuan bahwa setiap orang atau badan usaha yang 
memperdagangkan barang atau jasa wajib menyediakan data dan informasi secara lengkap dan benar. Pada Undang-Undang Perdagangan, e-commerce diatur dalam Bab VIII Perdagangan Melalui Sistem Elektronik pada Pasal 65 dan 66. Adapun bunyi Pasal 65 dan 66 UU Perdagangan adalah sebagai berikut:

Pasal 65

(1) Setiap Pelaku Usaha yang memperdagangkan Barang dan/atau Jasa dengan menggunakan sistem elektronik wajib menyediakan data dan/atau informasi secara lengkap dan benar;

(2) Setiap Pelaku Usaha dilarang memperdagangkan Barang dan/atau Jasa dengan menggunakan sistem elektronik yang tidak sesuai dengan data dan/atau informasi sebagaimana dimaksud pada ayat (1).

(3) Penggunaan sistem elektronik sebagaimana dimaksud pada ayat (1) wajib memenuhi ketentuan yang diatur dalam Undang-Undang Informasi dan Transaksi Elektronik;

(4) Data dan/atau informasi sebagaimana dimaksud pada ayat (1) paling sedikit memuat:

a. identitas dan legalitas Pelaku Usaha sebagai produsen atau Pelaku Usaha Distribusi;

b. persyaratan teknis Barang yang ditawarkan;

c. persyaratan teknis atau kualifikasi Jasa yang ditawarkan;

d. harga dan cara pembayaran Barang dan/atau Jasa; dan

e. cara penyerahan Barang.

5) Dalam hal terjadi sengketa terkait dengan transaksi dagang melalui sistem elektronik, orang atau badan usaha yang mengalami sengketa dapat menyelesaikan sengketa tersebut melalui pengadilan atau melalui mekanisme penyelesaian sengketa lainnya.

(6) Setiap Pelaku Usaha yang memperdagangkan Barang dan/atau Jasa dengan menggunakan sistem elektronik yang tidak menyediakan data dan/atau informasi secara lengkap dan benar sebagaimana dimaksud pada ayat (1) dikenai sanksi administratif berupa pencabutan izin.

Pasal 66

Ketentuan lebih lanjut mengenai transaksi Perdagangan melalui Sistem Elektronik diatur dengan atau berdasarkan Peraturan Pemerintah.

Pasal 65 dan 66 UU Perdagangan tersebut di atas telah mengatur dengan tegas hal-hal yang dilarang oleh pelaku usaha.Hal ini bertujuan untuk memberikan perlindungan hukum bagi 
konsumen. Hal yang sama sebagaimana yang juga diberikan oleh UUPK dan UU ITE untuk memberikan perlindungan hukum bagi konsumen. Hal ini agar konsumen memiliki rasa aman dalam bertransaksi dan konsumen terhindar dari berbagai hal yang merugikan.

\section{Penyelesaian Sengketa Konsumen E-Commerce}

Data dari Yayasan Lembaga Konsumen Indonesia (YLKI) menerima sebanyak 564 pengaduan sepanjang tahun $2018 .{ }^{15}$ Secara rinci YLKI mencatat, dari sejumlah aduan konsumen tentang jasa keuangan, aduan mengenai masalah perbankan mencapai 103 kasus, pinjaman online 81 kasus, asuransi 21 kasus, leasing 21 kasus, serta uang elektronik 8 kasus. Aduan dari sektor digital, YLKI jumlah aduan di sektor belanja online juga kerap dilaporkan konsumen dengan total sebanyak 40 kasus. Pengaduan ini umumnya terkait dengan barang pesanan tidak diterima 19 kasus, barang tidak sesuai aplikasi 7 kasus, transaksi tidak valid 3 kasus, pembajakan akaun serta pembatalan sepihak 2 kasus. Sedangkan 2 kasus lainnya merupakan masalah transportasi online. ${ }^{16}$

Banyaknya aduan oleh konsumen ke YLKI tersebut menunjukkan bahwa masih terdapat kerugian-kerugian yang dialami oleh konsumen Indonesia sehingga perlu upaya dalam hal penyelesaian sengketa konsumen tersebut. Penyelesaian sengketa konsumen sebagai salah satu bentuk mekanisme perlindungan konsumen, dapat ditempuh melalui pengadilan atau di luar pengadilan berdasarkan pilihan sukarela para pihak yang bersengketa. Penyelesaian sengketa konsumen sebagaimana dimaksud di atas tidak menutup kemungkinan penyelesaian damai oleh para pihak yang bersengketa.

UUPK membagi penyelesaian sengketa konsumen menjadi 2 (dua) bagian yakni:

1. Penyelesaian sengketa di luar pengadilan

a. Penyelesaian sengketa secara damai, oleh para pihak sendiri, konsumen, dan pelaku usaha/produsen; dan

b. Penyelesaian sengketa melalui Badan Penyelesaian Sengketa Konsumen dengan menggunakan mekanisme alternative dispute resolution, yaitu konsiliasi, mediasi, dan arbitrase.

2. Penyelesaian sengketa melalui pengadilan.

\footnotetext{
${ }^{15}$ https://katadata.co.id/berita/2019/01/25/ylki-layanan-jasa-keuangan-catat-aduan-konsumen-terbanyak-di-2018, YLKI: Layanan Jasa ${ }^{16}$ Ibid. Keuangan Catat Aduan Konsumen Terbanyak di 2018, diakses 2 September 2019.
} 
Berkaitan dengan penyelesaian sengketa konsumen dalam UUPK diatur dalam sejumlah pasal UUPK seperti Pasal 45 UUPK. Adapun bunyi Pasal 45 UUPK sebagai berikut:

a. Setiap konsumen yang dirugikan dapat menggugat pelaku usaha melalui lembaga yang bertugas menyelesaikan sengketa antara konsumen dan pelaku usaha atau melalui peradilan yang berada di lingkungan peradilan umum;

b. Penyelesaian sengketa konsumen dapat ditempuh melalui pengadilan atau di luar pengadilan berdasarkan pilihan sukarela para pihak yang bersengketa;

c. Penyelesaian sengketa di luar pengadilan sebagaimana dimaksud pada ayat (2) tidak menghilangkan tanggung jawab pidana sebagaimana diatur dalam undangundang.

d. Apabila telah dipilih upaya penyelesaian sengketa konsumen di luar pengadilan gugatan melalui pengadilan hanya dapat ditempuh apabila upaya tersebut dinyatakan tidak berhasil oleh salah satu pihak atau oleh para pihak yang bersengketa.

Berdasarkan Pasal 45 UUPK tersebut, terdapat beberapa mekanisme penyelesaian sengketa yang dapat ditempuh Konsumen yakni melalui pengadilan dan di luar pengadilan. Sedangkan Pasal 48 UUPK menyebutkan penyelesaian sengketa konsumen melalui pengadilan mengacu pada ketentuan tentang peradilan umum. Sementara itu, pasal lainnya dalam UUPK yang mengatur mengenai sengketa konsumen adalah Pasal 46 UUPK.

Pasal 46 UUPK:

1) Gugatan atas pelanggaran pelaku usaha dapat dilakukan oleh:

a. Seorang konsumen yang dirugikan atau ahli waris yang bersangkutan;

b. Kelompok konsumen yang mempunyai kepentingan yang sama;

c. Lembaga perlindungan konsumen swadaya masyarakat yang memenuhi syarat, yaitu berbentuk badan hukum atau yayasan, yang dalam anggaran dasarnya menyebutkan dengan tegas bahwa tujuan didirikannya organisasi tersebut adalah untuk kepentingan perlindungan konsumen dan telah melaksanakan kegiatan sesuai dengan anggaran dasarnya;

d. Pemerintah dan/atau instansi terkait apabila barang dan/atau jasa yang dikonsumsi atau dimanfaatkan mengakibatkan kerugian materi yang besar dan/atau korban yang tidak sedikit. 
2) Gugatan yang diajukan oleh sekelompok konsumen, lembaga perlindungan konsumen swadaya masyarakat atau pemerintah sebagaimana dimaksud pada ayat (1) huruf b, huruf c, atau huruf d diajukan kepada peradilan umum.

3) Ketentuan lebih lanjut mengenai kerugian materi yang besar dan/atau korban yang tidak sedikit sebagaimana dimaksud pada ayat (1) huruf d diatur dengan Peraturan Pemerintah.

\section{Penyelesaian Sengketa Konsumen di Luar Pengadilan}

Sebagaimana yang telah disebutkan, selain penyelesaian sengketa melalui pengadilan, UUPK juga mengenal penyelesaian sengketa konsumen di luar pengadilan. Penyelesaian sengketa konsumen di luar pengadilan dibutuhkan karena beberapa hal seperti proses penyelesaian sengketa yang tidak memerlukan waktu yang panjang dan memakan biaya yang banyak. Di lain sisi dalam dunia bisnis diharapkan sedapat mungkin tidak merusak hubungan bisnis antara penjual dan pembeli sehingga dibutuhkan solusi dalam menyelesaiakan masalah di luar pengadilan.

Menurut penyelesaian sengketa konsumen di luar pengadilan diselenggarakan untuk mencapai kesepakatan mengenai bentuk dan besarnya ganti kerugian, dan atau mengenai tindakan tertentu untuk menjamin tidak akan terjadi kembali atau tidak akan terulang kembali kerugian yang diderita oleh konsumen. ${ }^{17}$

Menurut Pasal 19 ayat (1) dan ayat (3) UUPK, konsumen yang merasa dirugikan dapat menuntut secara langsung penggantian kerugian kepada produsen dan produsen harus memberi tanggapan dan/atau penyelesaian dalam jangka waktu 7 hari setelah transaksi berlangsung. Sedangkan berdasarkan Undang-Undang Nomor 30 Tahun 1999 tentang Arbitrase dan Alternatif Penyelesaian Sengketa, cara penyelesaian sengketa di luar pengadilan dapat berupa konsultasi, negosiasi, mediasi konsiliasi atau penilaian ahli.

Adapun kerugian konsumen yang dapat dituntut sesuai dengan Pasal 19 ayat (1) UUPK terdiri atas kerugian karena kerusakan, pencemaran dan kerugian lain akibat dari mengkonsumsi barang dan/atau jasa. Bentuk penggantian kerugiannya dapat berupa; 1) Pengembalian uang

\footnotetext{
17 Susanti Adi Nugroho, Proses Penyelesaian Sengketa Konsumen Ditinjau dari Hukum Acara Serta Kendala Implementasinya, Jakarta: Kencana Prenada Media Group, 2008, hlm. 14.
} 
seharga pembelian barang dan/atau jasa; 2) Penggantian barang dan/atau jasa sejenis atau setara nilainya; atau 3) Perawatan kesehatan; atau 4) Pemberian santunan yang sesuai.

Mengenai tuntutan penggantian kerugian melalui Badan Penyelesaian Sengketa Konsumen (BPSK) Menurut Pasal 1 butir 11 Undang-Undang Nomor 8 Tahun 1999 tentang Perlindungan Konsumen, yang dimaksud dengan Badan Penyelesaian Sengketa Konsumen (BPSK) adalah badan yang bertugas menangani dan menyelesaikan sengketa antara Pelaku Usaha dan Konsumen.

Terbentuknya lembaga BPSK memberikan dampak kepada penyelesaian sengketa konsumen yang dapat dilakukan secara cepat, mudah dan murah. Namun berdasarkan penelitian terhadap konsumen e-commerce dalam perdagangan produk wanita di Kota Pekanbaru, meski telah dirugikan dalam bertransaksi tidak pernah membawanya ke lembaga BPSK. Hal ini sebagaimana bisa di lihat pada tabel berikut ini:

Tabel 3.2

Transaksi Yang Dirugikan

\begin{tabular}{|c|c|c|c|c|}
\hline No & $\begin{array}{c}\text { Nama } \\
\text { Konsumen }\end{array}$ & $\begin{array}{c}\text { Produk Wanita } \\
\text { yang Dibeli }\end{array}$ & $\begin{array}{c}\text { Bentuk Kerugian yang } \\
\text { Dialami dalam Membeli } \\
\text { Produk Secara Online }\end{array}$ & $\begin{array}{c}\text { Pernah/Tidak } \\
\text { Menyelesaikan } \\
\text { Sengketa } \\
\text { Konsumen } \\
\text { Melalui } \\
\text { Pengadilan/Di } \\
\text { Luar Pengadilan } \\
\text { (BPSK) }\end{array}$ \\
\hline 1. & $\begin{array}{l}\text { Dede Mutiara } \\
\text { Yaste }\end{array}$ & $\begin{array}{ll}\text { 1. } & \text { Jilbab; } \\
\text { 2. } & \text { Baju; } \\
\text { 3. } & \text { Kosmetik } \\
& \text { (lipstik) }\end{array}$ & $\begin{array}{l}\text { 1. Ukuran barang yang } \\
\text { dipesan tidak sesuai } \\
\text { dengan yang diterima; } \\
\text { 2. Tingkat kesesuaian } \\
\text { barang antara yang } \\
\text { dipesan dengan yang } \\
\text { diterima hanya sekitar } \\
\text { tujuh puluh (70) }\end{array}$ & Tidak Pernah \\
\hline
\end{tabular}




\begin{tabular}{|c|c|c|c|c|}
\hline & & & $\begin{array}{l}\text { persen. Tiga puluh (30) } \\
\text { persennya lagi } \\
\text { cenderung tidak sesuai } \\
\text { antara yang dipesan } \\
\text { dengan yang diterima. }\end{array}$ & \\
\hline 2. & $\begin{array}{l}\text { Rahmannur } \\
\text { Ikhuanza }\end{array}$ & $\begin{array}{l}\text { 1. Baju; } \\
\text { 2. Tas; } \\
\text { 3. Boks sepatu; } \\
\text { 4. Jam tangan } \\
\text { wanita. }\end{array}$ & 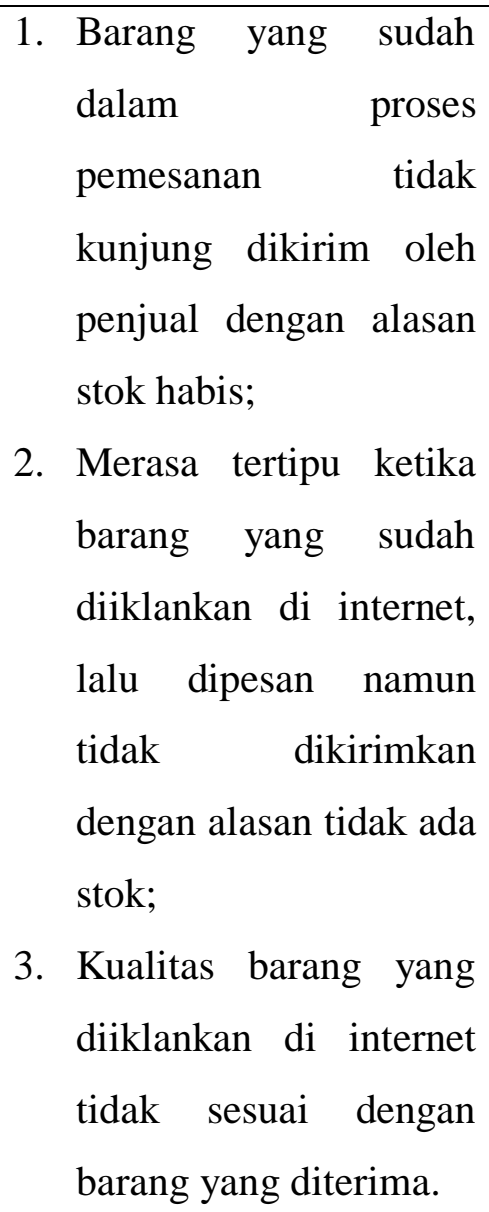 & Tidak Pernah \\
\hline 3. & Rini Ratna Sari & $\begin{array}{ll}\text { 1. } & \text { Baju; } \\
\text { 2. } & \text { Tas; } \\
\text { 3. } & \text { Jaket }\end{array}$ & 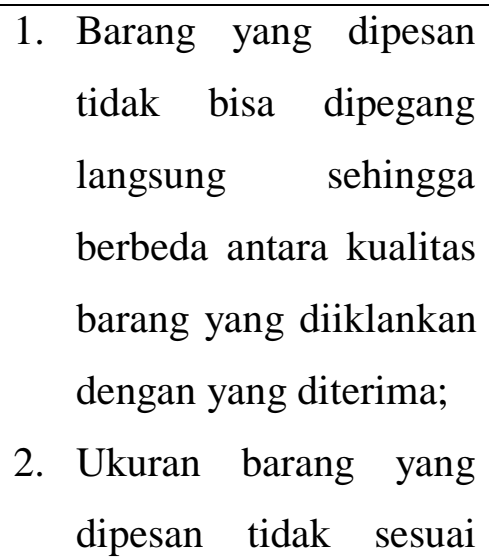 & Tidak Pernah \\
\hline
\end{tabular}




\begin{tabular}{|c|c|c|c|c|}
\hline & & & $\begin{array}{l}\text { antara yang dipesan } \\
\text { dengan } \\
\text { diiklankan; } \\
\text { 3. Tingkat kecerahan } \\
\text { warna tidak sesuai } \\
\text { antara yang diiklankan } \\
\text { di internet dengan yang } \\
\text { diterima; } \\
\text { Tidak bisa melihat isi } \\
\text { dalam produk (tas) } \\
\text { sehingga tidak bisa } \\
\text { mendapatkan informasi } \\
\text { sebuah produk secara } \\
\text { utuh. }\end{array}$ & \\
\hline 4. & Roza Efnita & $\begin{array}{l}\text { 1. Baju gamis; } \\
\text { 2. Jilbab; } \\
\text { 3. Tas; } \\
\text { 4. Sepatu. }\end{array}$ & 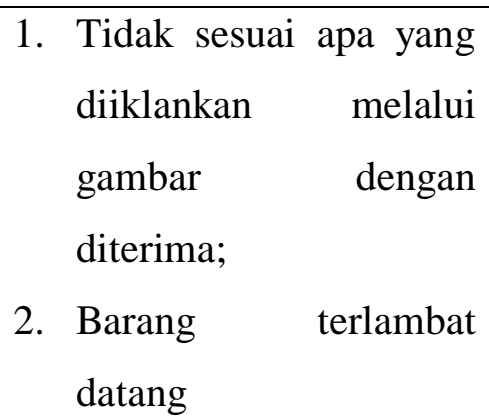 & Tidak Pernah \\
\hline
\end{tabular}

Sumber: Data diolah dari wawancara peneliti dengan konsumen dalam perdagangan produk wanita di Kota Pekanbaru tahun 2019.

Data tersebut di atas menunjukkan bahwa meskipun konsumen mengalami kerugian namun konsumen yang telah mengalami kerugian tersebut tidak pernah menempuh jalur pengadilan ataupun BPSK untuk menuntut kerugian yang telah dialami dalam bertransaksi. Hal ini disebabkan oleh beberapa hal seperti: konsumen tidak mau menempuh jalur pengadilan karena proses beracara yang lama adan berbelit, tidak tahu harus mengadukan kemana, tidak paham jalur pengadilan dan ataupun di luar pengadilan, dan tidak mau menempuh jalur pengadilan karena nilai uang yang dirugikan tidak terlalu besar. ${ }^{18}$ Akan tetapi keberadaan BPSK diharapkan

\footnotetext{
${ }^{18}$ Diolah dari hasil wawancara dengan konsumen e-commerce dalam perdagangan produk wanita di Kota Pekanbaru, tahun 2019.
} 
mampu menyelesaikan sengketa konsumen di luar pengadilan mengurangi banyaknya perkara yang masuk di pengadilan. Meskipun demikian, di Indonesia telah mulai dikenal oleh masyarakat sebagaimana tahun 2018-2019 terdapat sejumlah pengaduan yang masuk ke BPSK sebagaimana bisa dilihat pada diagram berikut ini:

\section{Gambar 3.1}

Pengaduan Yang Masuk ke BPSK Tahun 2018-2019
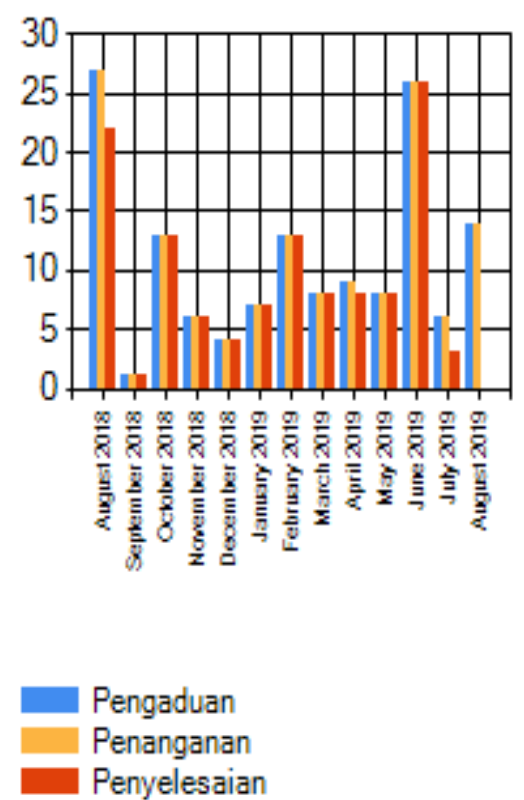

Sumber: Website BPSK (https:siswapk.kemendag.go.id/bpsk/212), diakses tanggal 31 Agustus 2019.

Diagram tersebut diatas menunjukkan grafik pengaduan yang dilakukan oleh konsumen ke BSPK mulai Agustus 2018 sampai Agustus 2019. Grafik tersebut menunjukkan sebahagian besar pengaduan yang masuk telah mendapatkan penyelesaiannya. Sedangkan BPSK itu sendiri dibentuk untuk menyelesaikan sengketa konsumen yang kecil dan bersifat sederhana. Adapun pola-pola penyelesaian sengketa konsumen di luar pengadilan yang dikehendaki UUPK, memang merupakan pilihan yang tepat, karena jalan keluar yang dirumuskan berisikan penyelesaian yang memuaskan kedua belah pihak yang sedang bersengketa. 


\section{SIMPULAN DAN SARAN}

\subsection{Simpulan}

Era globalisasi yang terjadi hari ini membuat batas-batas suatu negara akan menjadi kabur, di satu pihak terjadi keterkaitan antara ekonomi nasional dengan perekonomian internasional yang semakin erat. Hal ini ditambah lagi dengan pesatnya kemajuan teknologi dan komunikasi yang terhubung dengan internet. Di samping itu, pertumbuhan pengguna internet yang pesat membuat internet menjadi salah satu media yang efektif bagi perusahaan maupun perseorangan untuk memperkenalkan dan menjual barang atau jasa kepada konsumen dari seluruh dunia. Ecommerce merupakan model bisnis modern yang tidak perlu menghadirkan pelaku bisnis secara langsung dan tidak menggunakan tanda tangan asli. Meskipun terdapat keuntuntungan dan kelebihan dalam bertransaksi secara elektronik namun juga terdapat kerugian yang akan menimpa konsumen

Menjamin Perlindungan Konsumen, UUPK telah mengatur beberapa hal yang dilarang bagi pelaku usaha sebagaimana yang diatur dalam Bab IV 'Perbuatan yang Dilarang' Bagi Pelaku Usaha'. Dalam hal ini UUPK dapat memaksa pelaku usaha untuk mentaati isi UUPK.Dan hal ini ditegaskan pula dalam UUPK seperti pada Bab VI 'Tanggungjawab Pelaku Usaha'. Perlindungan hukum terhadap konsumen yang diberikan dalam UUPK dikarenakan seringnya terjadi pelanggaran terhadap hak-hak konsumen. Namun, meskipun UUPK telah memberikan sejumlah perlindungan terhadap konsumen masih terdapat konsumen yang tidak memahami isi UUPK dan tidak tahu akan hak dan kewajiban konsumen sehingga dalam penyelesaian sengketa, masih terdapat konsumen yang meskipun telah dirugikan tidak menempuh jalur pengadilan atau pun di luar pengadilan untuk menyelesaikan sengketa konsumen.

\subsection{Saran}

Perlunya pendidikan terhadap konsumen akan hak-hak dan kewajiban konsumen agar tidak dirugikan dalam bertransaksi. Disamping itu, konsumen e-commercediharuskan lebih selektif dalam transaksi jual beli e-commerce karena dalam transaksi e-commerce tidak bertemunya antara penjuak dan pembeli dan kontrak hanya dilakukan secara elektronik sehingga konsumen rentan mengalami kerugian. Di samping itu, ketika mengalami kerugian konsumen harus bisa menemukan cara yang tepat untuk menyelesaikan sengketa yang dialami, baik penyelesaian sengketa melalui pengadilan maupun penyelesaian sengketa di luar pengadilan. Karena permasalahan yang dihadapi konsumen Indonesia, seperti juga yang dialami konsumen di 
negara-negara berkembang lainnya, tidak hanya sekedar bagaimana memilih barang, tetapi jauh lebih kompleks dari itu yaitu menyangkut pada kesadaran semua pihak, baik itu pengusaha, pemerintah maupun konsumen sendiri tentang pentingnya perlindungan konsumen.

\section{DAFTAR PUSTAKA}

\section{Literatur}

Agus Yudha Hernoko., Hukum Perjanjian Asas Proporsionalitas dalam Kontrak Komersial, Jakarta: Kencana Prenada Media Group, 2013.

Ahmadi Miru, dan Sutarman Yodo, Hukum Perlindungan Konsumen, Jakarta: PT RajaGrafindo Persada, 2010.

Danrivanto Budhijanto, Hukum Telekomunikasi, Penyiaran dan Teknologi Informasi: Regulasi dan Konvergensi, Bandung: PT Refika Aditama, 2010.

Gemala Dewi, dkk, Hukum Perikatan Islam Di Indonesia, Depok: Prenadamedia Group, 2018

Onno W. Purbo dan Tony Wiharjito, Keamanan Jaringan Internet, Jakarta: PT. Elex Media Komputindo, Kelompok Gramedia, 2002.

Sukarmi, Cyber Law Kontrak Elektronik Dalam Bayang-Bayang Pelaku Usaha, Bandung: Pustaka Sutra, 2008.

Susanti Adi Nugroho, Proses Penyelesaian Sengketa Konsumen Ditinjau dari Hukum Acara Serta Kendala Implementasinya, Jakarta: Kencana Prenada Media Group, 2008.

Wawan Muhwan Hariri, Hukum Perikatan Dilengkapi Hukum Perikatan Dalam Islam, Bandung: CV Pustaka Setia, 2011.

Wahyu Daniel, Wow! Transaksi e-Commerce RI 2018 Capai Rp 77 T, Lompat 151\%,https:/www.cnbcindonesia.com/tech/20190311101823-37-59800/wow-transaksie-commerce-ri-2018-capai-rp-77-t-lompat-151

https://katadata.co.id/berita/2019/01/25/ylki-layanan-jasa-keuangan-catat-aduan-konsumenterbanyak-di-2018, YLKI: Layanan Jasa Keuangan Catat Aduan Konsumen Terbanyak di 2018

https://siswapk.kemendag.go.id/bpsk/212)

Undang-Undang Nomor 5 Tahun 1999 tentang Larangan Praktek Monopoli Dan Persaingan Usaha Tidak Sehat

Undang-Undang Nomor 8 Tahun 1999 tentang Perlindungan Konsumen

Undang-Undang Nomor 30 Tahun 1999 tentang Arbitrase dan Alternatif Penyelesaian Sengketa

Undang-Undang Nomor 11 Tahun 2008 tentang Informasi dan Transaksi Elektronik

Undang-Undang Republik Indonesia Nomor 7 Tahun 2014 tentang Perdagangan 